\title{
Adam Yuet Chau, Miraculous Response: Doing Popular Religion in Contemporary China
}

Katiana Le Mentec

\section{OpenEdition}

12 Journals

Electronic version

URL: http://journals.openedition.org/chinaperspectives/3943

DOI: $10.4000 /$ chinaperspectives.3943

ISSN: 1996-4617

Publisher

Centre d'étude français sur la Chine contemporaine

\section{Printed version}

Date of publication: 4 April 2008

Number of pages: 114-116

ISSN: 2070-3449

\section{Electronic reference}

Katiana Le Mentec, « Adam Yuet Chau, Miraculous Response: Doing Popular Religion in Contemporary China », China Perspectives [Online], 2008/2 | 2008, Online since 01 April 2008, connection on 24

September 2020. URL : http://journals.openedition.org/chinaperspectives/3943 ; DOI : https://doi.org/ 10.4000/chinaperspectives.3943

This text was automatically generated on 24 September 2020.

(c) All rights reserved 


\title{
Adam Yuet Chau, Miraculous Response: Doing Popular Religion in Contemporary China
}

\author{
Katiana Le Mentec
}

1 Adam Chau's work has resonated widely among English-speaking Sinologists following the publication of his book, Miraculous Responses - Doing Popular Religion in Contemporary China. Chau, currently a lecturer in modern Chinese anthropology in the Department of East Asian studies at Cambridge University, has examined the reemergence of popular beliefs and practices in China. A long ethnographic study -18 months - between 1995 and 1998, carried out as part of his doctoral research, enabled him to observe the organisation of a temple dedicated to the Black Dragon King (heilong wang miao) in the prefecture of Yulin, in the heart of the Valley of the Dragon King in the Shaanbei region (north of Shaanxi province). Basing his approach on concepts drawn from classical and contemporary sociology, Chau develops in this book an analysis of the popular religious activities that he witnessed. The body of theory within which he proposes to analyse the socio-cultural process of what he calls "doing popular religion" aims at moving beyond the study of "purely religious" practices and beliefs such as prayer or burning incense: he includes a more general reflection on participation and on the organisation of religious activities, as well as on the sociality they give rise to. Chau deploys his observations to show how the practice of religion is a phenomenon deeply rooted in its political and social context. He explains, through the medium of a remarkable ethnographic study, how the field of popular Chinese religion forms an interactive space between the elite, the local authorities, and peasant society. The writer points out the "political, economic and symbolic resources" created by religious institutions and activities, a real theatre of the ambitions and interests of a diverse local range of social forces. His book can thus be read as an ethnographical study of the balance of power within the Chinese village, and of the changing relationship between the state and society since the beginning of the reform era. 
2 The book is a clear and highly structured piece of work. Its 12 chapters include an introduction and a conclusion: the inner ten chapters are of more or less equal length. Following the classic progression, the writer devotes the early chapters to presenting the general framework of the study, including the history, the cultural context, and regional society. He sets out the rural life of the locality, describing social structures and the organisation of politics, and goes on to present a panoramic view of Shaanbei's history and popular religion. He presents its practices and ritual specialists and then inquires into beliefs and religiosity in Shaanbei. At the end of the fourth chapter, Chau introduces his idea of modalities of "doing Religion" in Chinese culture. In his quest to identify the nature of religious belief among the Shaanbei peasants, he attempts to determine elementary structures of popular religious practices. He chooses to analyse the dynamic tensions by which Chinese religious ideas and practices alternately converge and diverge, focusing on practices rather than on conceptions. In this way he identifies five modalities that govern how people or groups practise popular religion in China. In particular, the author says, the religion of the Shaanbei peasants is a combination of what he calls the "relational" mode and the "immediate-practical" mode. ${ }^{1}$

Chapter 5 presents the history of the cult and the temple of the Black Dragon King, a typical example in the Chinese countryside. The author goes on to set this place of worship within its local context at the time of his enquiry. Here he reflects on the act of writing or inscribing, which he describes as "text act," citing as an example the steal erected in the temple. Chau suggests that in China the physical presence of these inscriptions, as powerful marks of legitimacy, produces a more significant effect on visitors to the site than the content of the texts.

The following three chapters $(6,7$, and 8$)$ deal with the structure and administrative organisation of the temple complex in the Valley of the Dragon King (Longwanggou). Indeed, in addition to the temple, the site being investigated includes, under the same management, a primary school, an arboretum, a kitchen, and numerous other premises. The author concerns himself here with the association in charge and its activities. He concentrates on aspects that he considers to have been often ignored by researchers into popular religion in China. Thus, having described the place, the people working there, and the forms of divination practised, Chau portrays the daily activities of the temple association as the manager of money, offering the example of incense money donations (Chapter 6). He undertakes a rational economic analysis of the religious practices. The temple activities are driven by a need (i.e. for miraculous efficiency - ling), and require various services (with religious specialists competing to provide them); they function according to the principle of "religious consumption." Chau goes on to examine sociality and the relationships formed by religious events, comparing the examples of a funeral ritual and the temple's annual festival. By throwing light on the principles of event production and organisation, he underlines the importance of "hosting" (Chapter 7), and the emphasis attached to ambience and "red-hot" sociality (honghuo in the local dialect corresponding to renao in Mandarin a fundamental Chinese concept). The author observes that these events provide an ideal opportunity for the people of Shaanbei to produce and experiment with honghuo, which in this culture is the most desirable state, and which is very beautifully described and extensively analysed by the author in Chapter 8 . For Chau, reciprocity, sociability, and the feelings produced during these events, far from being less significant than 
liturgical activities, represent an essential part of the analysis of religious practice even more important for the believer than the symbols of the ritual. Lastly, the author looks at these "event productions" in terms of ritual, setting the honghuo sociality that he has observed alongside Durkheim's "collective effervescence": he suggests that these religious events should be considered rites of convergence. In the last three chapters $(9,10$, and 11), the author deepens his study of the relationships at the local level between peasant society, the elite, and the state, insofar as they are constituted within the sphere of popular religion. Recounting the peculiar story of Lao Wang, who became head of the village and head of the temple (Chapter 9), he looks into the question of new local elites in rural China. Chapter 10 deals with the political platforms of the temple and the village. They are presented as a nexus, a source of legitimacy, where the dynamics and power struggles between different factions are played out. Chau devotes Chapter 11 to discussing how politics and religion go hand in hand in the peasant world: he introduces a final concept, that of the "channelling zone," understood as an abstract space where networks of established relationships are developed autonomously by various official agencies with local organisations (the temple association, for example). The writer describes the common interests shared among these entities and offers examples of mutual accommodation and legitimisation strategies. He returns here to his reflection on the "text act," a crucial element in the legitimisation of institutions in Chinese political culture.

Miraculous Response: Doing Popular Religion in Contemporary China is an important contribution to the study of popular religion and local society in China. The book is intended for a general readership. Students in particular will find the work a valuable textbook from start to finish, throwing light on key questions and previous research in a very educational way, while revealing the author's constant concern with addressing academic debates and taking his own stand within them. ${ }^{2}$ Novices, too, will discover a rich ethnography of the spheres of culture and popular religion, and also that of social life in the present-day Chinese countryside. Plunging the reader into a narrative bursting with detail, minor histories, and anecdotes, the author agreeably communicates his fine understanding of Chinese culture. With this book, Adam Chau positions himself as both an ethnographer and a theoretician in the study of religion, whose theses and concepts deserve to be debated and extended.

7 Particularly to be appreciated is the space allotted to the study of temple management and local interactions. Here, Chau commits himself to the political anthropology of the "small," while avoiding the pitfall of seeing state and people simplistically opposed to one another. The notion of text act, as presented in Chapter 5 and referred to regularly throughout the book, offers an interesting analysis and reminds us of the primacy of the written word in China, already attested by numerous authors. Chau is careful to cite full translations of his texts and to include them in the body of the work rather than as appendices, thus allowing them to speak for themselves. The practice of ethnography demonstrates here its greatest strength: the ability to restore the context within which such writings were created thanks to the observations of a researcher who is not only witness to but also participant in the process.

8 Yet, a few reservations must be expressed concerning the beginning of Chapter 4, with its somewhat unconvincing attempt to explain religious "conceptions" in Shaanbei. Having developed a comparison - in my view hard to sustain - with Christian "religiosity," Chau himself acknowledges the incomplete and oversimplified character 
of this presentation. This point is linked more generally to the book's manifestly "positivistic" bias. ${ }^{3}$ Throughout, Chau classifies and systematises in an abstract way the reality that he observes. He refers one by one to general models drawn from the classic sociology of Durkheim, concepts taken up by Bourdieu or of Marxist inspiration, ${ }^{4}$ or more indirectly to methods of analysis developed by Weber ${ }^{5}$ or Lévi-Strauss. ${ }^{6}$ For example, he seeks to explore "the cultural logics" (p. 2), to give a "framework" to religious life; he proposes to identify the "elementary structures of popular religion," to recognise six basic principles defining the believers and religious practices in Shaanbei, and lastly to categorise popular religious practices within five broad "modalities" (Chapter 4). So it is to be regretted that the ethnographic study, rich and agreeably conveyed though it is, seems to have been confined rather artificially within general categories rather than being given the opportunity to reach its full and most revealing potential. Lastly, with hindsight, it is hard to tell whether the analysis is inspired by observation or whether ready-made theoretical models have been superimposed on the material. This criticism is not intended to challenge the usefulness of these conceptual tools and typographies, but to underline the book's somewhat pervasive systemisation.

9 To sum up, Adam Chau's achievement in viewing the sphere of popular religion in China in all its aspects deserves applause. Even though the book is not a "revelation" as suggested on its dustjacket - of the full complexity of popular religious practices, it does make an appreciable contribution to this field of research. The writer offers us a case study through a staging of religion, which produces but also reveals the social interplay and the power relationships of rural China. With this piece of work, the writer has taken his place in an exciting, necessary, and legitimate field of anthropological research, concerning himself primarily with religion but allowing wider social and communal phenomena to appear. In fact, Chau displays some affinities with Kenneth Dean, ${ }^{7}$ if not with his methodology, at least with his areas of interest. Dean, cited in the bibliography, called attention, with a fine analysis of his material, to the importance of the rituals of local communal religion as arenas for the negotiation of modernity in contemporary China.

One may regret that the author does not make greater mention of numerous other recent studies carried out within his discipline, which have focused on different cultural spheres and developed similar reflections. French anthropology, for example, is also concerned with these processes and with the relationships formed and represented in the course of religious events. By way of example, one might cite the work of the ethnologist Elisabeth Claverie. She gives an account of relationships among participants, organisers, different religious specialists, and state agencies, in the context of the popular pilgrimage to the site of the Virgin's appearance in Medjugorje in Croatia during the war in former Yugoslavia. ${ }^{8}$ Like Chau in his book, Claverie broadens the scope of her analysis to encompass the economic and political context. We might also liken Chau's theoretical aims to the propositions of Houseman and Severi. ${ }^{9}$ These anthropologists have studied material gathered by Bateson in a fresh light to formulate a new theory of ritual. They have seen in the ritualisation of the naven a "particular mode of action" establishing "a particular type of relational configuration" between participants that they perceive as different for each ritual. ${ }^{10}$ Similarly, Chau, in his book, presents an analysis of the relationships, but a more general one, created through popular religious events. 
11 All in all, Adam Chau's book is a thought-provoking study, and for this reason deserves to be warmly recommended.

\section{NOTES}

1. The other three modalities of religious practice are: the discursive or scriptural mode, the personal or cultivational mode, and the liturgical or ritual mode. They are succinctly presented on page 75 . Chau had the opportunity to elaborate his thinking and back it up with examples in his presentation to the International Conference on Religion and Social Integration in Chinese Societies, held at the Chinese University of Hong Kong on 28 June 2007.

2. One might find fault with the indexation: some references have patently been forgotten. For example, Feuchtwang is quoted on pages 73 and 194, but the citations do not appear in the list of attributions to this author.

3. I am referring to the principle of knowledge developed by Auguste Comte (1798-1857), who practiced a scientific sociology, seeking constant relationships between variables, similarities, or laws.

4. For example, he borrows the Harrell's typology of believers by speaking of "four basic forms of religious habitus" (p. 67). He also speaks of "social classes" and "social stratifications" (p. 27).

5. Indeed, Chau plainly seems to be strongly influenced by Max Weber's typology of rational action and his concept of ideal-type, which consists in gathering together under one coherent definition all the specific and most distinctive features that characterise an object. Equally, he seems to assume a theory of "actors" following rational strategies guided by "needs" and attracted by "resources."

6. It is a structural analysis that he seems to be developing in his book.

7. Kenneth Dean, Local Communal Religion in Contemporary South-East China, The China Quarterly, 2003, 174, pp. 338-58.

8. Elisabeth Claverie, Les guerres de la vierge, une anthropologie des apparitions, Paris, Gallimard, 2003, $452 \mathrm{pp}$.

9. Michael Houseman \& Carlo Severi, Naven or the Other Self: A Relational Approach to Ritual Action, Michael Fineberg, 1998, 325 pp.

10. Ibid, p. 262 